\title{
EMOTIONAL RESPONSES OF CORRECTIVE FEEDBACK IN TEACHER TRAINING CLASS AT UNIVERSITY LEVEL
}

\author{
J. Ari Wibowo \\ Program of English Education, Faculty of Teacher Training and Education, UN PGRI Kediri \\ Jalan KH Achmad Dahlan st No. 76, Kediri, East Java \\ j.ariwibowo24@gmail.com
}

\begin{abstract}
Considering and comprehending the right way of student in learning are requirement to become an effective language teacher. This study present the findings of research carried out to collect data of learner's emotional respond to oral corrective feedback process. In this research, the researcher uses both qualitative and quantitative approach. It is qualitatively describe the emotional respond of the students to the teacher's corrective feedback on their performances in microteaching class at University of Nusantara PGRI Kediri by collecting the data based on planning and conducting skill of an instruction. The data base comprises questionnaire of students' emotional respond of the feedback in the naturalistic classroom situation. The quantitatively analysis of the data showed that more than half of the corrective feedback made by the teacher is appreciated and needed by the students. However, consistency would become a crucial point for them. It is, thus, recommended that this line of enquiry be followed-up by other researcher so that teachers, teacher trainers and policy makers.
\end{abstract}

Key word: corrective feedback, emotion, respond, classroom situation

\begin{abstract}
ABSTRAK
Mempertimbangkan dan memahami cara yang tepat dalam pembelajaran siswa merupakan persyaratan menjadi seorang pengajar bahasa yang efektif. Penelitian ini menggambarkan temuan penelitian dalam pengumpulan data respon emosional siswa terhadap proses umpan balik korektif lisan. Dalam penelitian ini, peneliti menggunakan dua pendekatan, yaitu pendekatan kualitatif dan kuantitatif. Penelitian ini secara kualitatif menggambarkan respon emosional siswa terhadap umpan balik korektif guru pada perfomansi siswa dalam kelas microteaching di Universitas Nusantara PGRI Kediri dengan menggumpulkan data berdasarkan perencanaan dan pelaksanaan kemampuan pemberian instruksi. Data penelitian berasal dari kuesioner respon emosional siswa terhadap umpan balik di dalam situasi kelas yang naturalis. Secara kuantitatif, analisis data menunjukkan bahwa lebih dari setengah umpan balik korektif yang dilakukan oleh guru diapresiasi dan diperlukan oleh para siswa. Namun, konsistensi menjadi hal yang sangat krusial untuk siswa. Oleh karena itu, penelitian ini diharapkan dapat dikembangkan oleh para peneliti lainnya, pelatih guru dan pembuat kebijakan.
\end{abstract}

Kata kunci: umpan balik korektif, emosi, respon, situasi kelas 


\section{INTRODUCTION}

Feedback is one of error correction concept. Feedback is widely identified in information theory and general communication research outside classroom or language learning contexts as it is said by Annett as cited in Chaudron (1998). Teacher expects perform their instructional right to assess all student performance. However, inconsistence unwanted result which ignore negative evidence for learner's mistake should be taken appropriate. When it fossilized, it would be difficult to correct. Troike (2006) explained that likelihood of fossilization for L2 learners is strong. Learners will cease their IL development in some respects before they reach target language norms, in spite of continuing L2. Based on it, corrective feedback can be the answer in order to avoid that situation. Corrective feedback is one of the important things in the instruction. Learner often makes mistake in his study. However, it is common things within. Learner may learn more by their mistakes when the teacher provides them with correction on their mistake or negative evidence. In other word, learner acquires the subject not only by learning anymore.

Based on previous study presented by Mahdy and Saadany (2013) entitled "Oral Feedback in the EFL Classroom", this study exposed the importance of learners preferences where the teacher could adjust feedback types depending on what the students prefer. It defined that oral feedback is important both for teacher and students. However, oral feedback has the consequences of could sound denouncing and could discourage students. In this study, some interviewed teacher preferred using elicitation and praising, they need to be consequent to make the students aware why they get this kind of feedback. In other hand, since the teachers did not want to correct the students in order not to discourage them there could be other options that belong within the category of interactional feedback.

It becomes supporting condition where feedback is really important to do during instruction. However, it is also a supporting awareness to be considered in doing it. Various students' personality could give various responses which may not in line with the teacher's intention. Based on the problem above, this study is intended to find out the effect or corrective feedback in term of the students' emotion.

Corrective feedback could be in written or oral form. It also can be in the various forms, such as comment, information, or question for learners which shows learner's error in the usage of the language. Corrective feedback is an indication to a learner that his or her use the target language is incorrect, and includes a variety of responses that a language learner receives. Corrective feedback can be explicit (e.g. "No, you should say goes, not go.") or implicit (e.g. "yes, he goes to school every day"), and may or may not include meta- linguistic information (e.g. "Don't forget to make the verb agree with the object.") (Lightbrown and Spada, 1999). So that, its function is to activate learner's self change behavior as he is given information of his errors.

Corrective feedback provides opportunities for learner corrections which is very helpful for them. Some other things related to corrective feedback are negotiation and uptake. Corrective feedback provides opportunities for learner corrections, and if there is no reaction on the part of the learner, no negotiation has taken place; consequently, there is a topic continuation. While uptake is the 
learner's respond to the teacher's feedback. Uptake can occur when learners themselves initiate focus-onform move, Ellis et al. (2001a).

"Corrective feedback has three basic theories. The three main theories are based on the behaviorist perspective, the innate/linguist perspective and the interactional/ developmental perspective" (Lightbrown and Spada, 2006:10-17). The behavioral approach focuses on habit that it needs input and reinforcement in the process of learning. The reinforcement is both for correct and wrong thing. input and reinforcement are applied for correct thing and also negative reinforcement for mistakes. Habit is the main role based on this theory since learner's language device is ready 'to be formed'. "Learners had a blank canvass and had input for language acquisition through imitation of a set of habits" (Woozley, 2012:3). "All learning verbal or nonverbal takes place through the establishment of habits which were development based on input from the environment" (Xiangui, 2005:121). Though the theory based on habit, however, errors also exist. Based on this theory, errors in second language were seen as interference from habits acquired in the first language (Woozley, 2012:2). Behaviorism sees error as a symptom of ineffective teaching or as evidence of failure (Maicusi et al., 2000:2).

The innate perspective on language acquisition is based on Chomsky. In the innate theory, language acquisition is not known as habit formation. Innate means everyone has capacity to learn language since they were born. Chomsky sees language acquisition as the gradual, creative build up to knowledge systems, resulting in implored general competence, rather than performance of habits in isolated instances by using rational, logic, reason extrapolation and inference (Woozley, 2012). "The innate perspective is based on cognitivist which is related to the idea that language is rule formation not habit formation" (Odo, 2007:219). By innatist approach, error is needed for progress.

The third theory is social interactionism language acquisition. Language acquisition is achieved through the operation of the social context which relates to the negotiation of meaning not just the one-way process of comprehensible input. "The social interactionism approach view errors as a social norm as well as a cognitive process" (Maicusi et. al., 2000:2). Errors by native speakers are seen as slips of the tongue and as unwanted forms if made by second language learners.

Emotion refers to transient feeling or affective responses to an event, object or person. Despite a generally accepted layperson understanding of emotion (i.e., you know it when you see/feel it), its definition can vary quite a bit across researcher and discipline (Barret, 1999). People can express their emotion on their own way by their mimics, gesture, utterance etc. It shows the responses of what they face in affective perspective. However, it is different from temperament in which Kagan (2010) explained that temperament referring to relatively stable or long-term tendencies toward, for example, happiness or grumpiness. In case of education, it is also an important thing to be included in the list of consideration since it affects students' cognition during learning process.

Emotion plays an essential role within cognition because it is an unconsious and nearly automatic human response to environment stimuli 
(Lazarus; Wofford and Daly, 1997). When they get an expected stimulus, it can raise their willingness and enthusiasm in joining the instruction. It is resulting to proper atmosphere for students to study and suitable condition for teacher for giving the material. In other hand, emotion and mood are different things. Emotion needs something as a trigger on it existence. Likewise, emotion and mood can be differentiated by the presence or absence of an event or object that elicited the person's feelings (e.g., emotions have objects of elicitation while moods do not or at least not necessarily; Parkinson, Totterdell, Biner and Reynolds, 1996).

Emotional response is a reaction in the perspective of affective in condition one get. One's response is a natural and unconscious action. Emotional reaction is defined as a reaction to various expressively crucial occurrences, authentic or possible, precedent or predictable. An emotional reply reveals intrinsic attractiveness thoughts occurring as result of selfrelated actions (Niazi et. al, 2012). By giving corrective feedback, students' brain would automatically respond in various ways since it relates the conducted action with different part of brain and also may be influenced by personality which causes different level of pleasure for each student. Morris et. al. (2009) defined that human emotions are multidimensional and that selfreport techniques for emotional response along the pleasure and arousal dimensions correspond to a specific task but different functional regions of the brain.

In line with marketing discipline, emotion plays significant role. Garner (1985) defined that information processing is affected by emotion through mood states and also it positive attitude can be created toward the ad and makes positive image to its brand. Emotion could also influence mood in processing information when students get a corrective feedback. In the right way, it makes information process run well and smoothly resulting to the teacher's correction could be received, accepted and implemented by the students. In the other hand, it decreases students' mood and anticipated by the student if it is conducted wrongly. Based on the theories there is no any chance for the teacher in neglecting emotion of the students when giving corrective feedback. Though corrective feedback is intended to give negative evidence, there are other things which influence its effectiveness and success. Emotion as an intrinsic factor of the students can support information to be comprehended easier. As stated by Carstensen and Mikels (2005) that emotion makes information become more salient.

\section{METHOD}

The present study is conducted on the basis of descriptive and study. It applies descriptive qualitative research and quantitative as well. The qualitative research is done to describe interview data result. While questionnaire data result is analyzed quantitatively by calculate them in percentage. They involve data that describes feedback effects, depiction of their feeling and experiences in learning, and description of the data collection. This study is conducted in UN PGRI Kediri for two months in March and April 2016.

Subject of the study are 10 university students taking peer teaching or microteaching in their $6^{\text {th }}$ semester. Data are collected using interview and questionnaires to find out their feeling and experiences in learning. The questionnaire is about the learner's 
perception about the feedback they get. How they respond the feedback, how important for them, and what they feel during and after getting the feedback. The questionnaire uses Likert scale: totally disagree, disagree, don't know, agree, and totally agree. Each scored 1 , $2,3,4$ and 5 respectively. In this type of questionnaire, there is a blank space where the respondent can express their further specific comments about their perception. Data collected were analyzed and interpreted descriptively.

The study tries to understand how students emotionally respond the feedback, how important for them, what they feel during and after getting the feedback and their experience during learning. It does not aim to measure students' achievement; instead it tries to investigate the effect beyond the feedback given. In line with the previous description, the principal method of data collection is using questionnaire and interview.

Before the data are collected, classroom observations are used to enhance an understanding of how the process, and particularly in relation to aspects relevant to the corrective feedback as well. The process is 40 minutes duration of each student to perform in teaching their own friends. They are given chances to choose topic, learning model, material, and media by themselves. The activities are scheduled for three to four times a week as the agreement of the students and the lecturer. Detail information was collected through interview to support the deeper ones. The researcher carries out interview to understand the view of the students of the topic, learning model, material and media they choose, and the other to explore issues arising from the observations and the students' data.
After the researcher observe the processes and get information from interview and questionnaire, the observational and interview data were assigned codes which represented the interpretation of the feedback effects. For the purpose of this research, the main one is about data reduction and selection of example from the case report. Descriptive analysis is applied to describe a clearer, more analytical interpretation of the data and review of the student emotion while quantitative is used to analyze the result of questionnaire about the students' feeling, experience, and effects of the feedback given.

\section{RESULTS AND DISCUSSION}

The finding addresses the effects of corrective feedback; where students positively react to the feedback given. It shows on the point of they have learned a lot from being orally corrected; $70 \%$ agree and $30 \%$ strongly agree. $70 \%$ feel happy and $30 \%$ are overwhelmed after receiving oral feedback. The positive reaction of the students, are based on some different points during the process. It is started from lesson plan, learning model, learning media, class management, scoring task etc. the corrective feedbacks were done in informal format and communicative situation in order to give convenient atmosphere to them.

The program is done by giving each student a chance to perform their skill in teaching. They were given 40 minutes time duration started from opening the class up to ending it. It means they have to show all skills from beginning until the end of an instruction. After that, the assessment is taken from two kinds of skill; they are skill of planning the instruction and the second one is skill of conducting the instruction. The corrective feedback is 
given to the students after they finish the performance session.

The first feedback given to the students is about the format of the lesson plan, then learning model application, the third is class management ability including confidence facing problem in the class. Confidence seems still become fundamental problem for students which highly influence most of their performance during the process.

However, nothing is perfect. Corrective feedback is claimed to have positive outcome but it also has the negative one. Among data about events, feedback effects, depiction of their feeling and experiences in learning, various carracteristic of students make different reaction especially in point of depiction of feeling and experiences in learning. Most of the students explain that they have learned a lot of thing, get necessary skill, helpfull knowledge and tangible improvement from being orally corrected. In another hand, depiction of students' feeling is different. $100 \%$ of the students are worry about making oral mistakes in language class. $40 \%$ Students are afraid when teacher is ready to give oral feedback. $30 \%$ are upset when they do not understand during correction feedback. $60 \%$ of the populations feel sorry of being orally corrected, $20 \%$ are resentful, $20 \%$ are nervous, $10 \%$ are embarrassed, $10 \%$ feel bothered but $0 \%$ feel indifference. While based on interview all students have pretension on the teacher's patience. $90 \%$ students accept the feedback pleasantly when teacher give the feedback patiently and gently but in short, clear and comprehensible explanation.

Judging from the interview and observation related to students' improvement of their performance, it shows corresponding positive result.
The students' perception of instruction has changed as they get more understanding what and how they should be. When they make any mistake, they can learn from the given feedback by the teacher which gives a clear direction to go. In the end they get more confidence in their performance. They have more confidence after knowing clearly the expected performance level and the way to perform in that level. They even improve themselves by finding some other techniques which help them to be better since they have known the right track.

The model also gives clear evidence for the teacher to have detail skill assessment. By applying the model, he always guides his students by the time he has the subject assessment. He will never miss the students' mistake as he follows and gives them negative evidence while assessing. Students will not forget the mistake and the negative evidence since they are closely related in short period of time. The other positive sides of the corrective feedback based on the previous description are the ability to provide a reliable self reflection and also an expected standard outcome.

In another hand, they way of teacher in giving feedback should be patiently and gently since most of students' characteristic demand it, although $10 \%$ are welcome in any condition. Teacher also should consider about the students' immediate feeling after being given feedback such as resentment, botheration, embarrassment, and so forth.

\section{CONCLUSION}

In conclusion, the outcome of corrective feedback on the students' emotion and instructional skill are positive, but teacher should give the 
feedback patiently and gently to avoid emotional side effects. As shown by the students' positive acceptance about the feedback in the observation and interview. Most of them admitted that it is helpful and they could be a flexible learner, feedback invites studentgenerated repair (self- or peer-repair). In term of emotion, students are also happy and overwhelmed since they have learned a lot of important and helpful thing to improve their skill. Patient and gentle way in providing feedback are required to prevent negative emotion such as resentment, embarrassment, botheration etc. teacher's consistency of explanation in short, clear and comprehensible are also demanded by the students. The teacher can also monitor the improvement clearly, as he follows each student's performance before giving feedback. He is also able to control all the improvement to the standard easily.

Finally, the suggestion is purposed for English teachers. The researcher suggests them to use corrective feedback which gives their students negative evidence or positive feedback on each student's mistake. It would be a precious sign for students to analyze the problem and try to find solution to the problem as well. The students are suggested to learn from their mistake after getting negative evidence from their teacher. They can also develop their speaking ability by the time they get the positive feedback of their performance. Then, for the other researcher, the researcher hopes that other researchers could improve the content of this research by adding more explanation, example, and references.

\section{REFERENCES}

Barrett, L. F., \& Russell, J. A. (1999). Structure of current affect. Curr Direct Psychol Sci, 8, 10-14.
Chaudron, C. (1998). Second Language Classrooms. Research on Teaching and Learning. NY: Cambridge University Press.

Ellis, R., Basturkmen, H., \& Loewen, S. (2001a). Learner uptake in communicative ESL lessons. Language Learning, 51(2), 281318.

Kagan, J. (2010). Emotions and Temperament. In: Bornstein M. H. editor. Handbook of Cultural Developmental Science. New York: Psychology Press.

Lightbrown \& Spada. (2003). How Languages are Learned. Second Edition. Oxford University Press.

Long, M. H. (1991). Focus on Form: A Design Feature in Language Teaching Methodology. In K. de Bot, R. Ginsberg \& C. Kramsch (eds.), Foreign Language Research in Cross-Cultural Perspective. Amsterdam: John Benjamins.

Maicusi, T., Maicusi, P., \& Lopez, M. J. C. (2000). The error in the second language acquisition. Encuentro, $11,168-173$.

Morris, J. D, et. al. (2009). Mapping a multidimensional emotion in response to television commercials. Human Brain Mapping, 30, 789-96.

Niazi, M. A. K, Ghani, U., \& Aziz, S. (2012). The emotionally charged advertisement and their influence on consumers' attitudes. International Journal of Business and Social Science, 3(1), 307-320.

Odo, J. C. (2007). Basic Methods, Consideration and Strategies in Language Teaching. In Anasiudu, B. N., Nwaozuzu, G. I. and Okebalama, C. N., Language and Literature in a Developing Country. Essays in honour of Professor Benson O. A. Oluikpe. 
Onitsha: Africana. First Pulishers Limited.

Parkinson, B, et. al. (1996). Changing Moods: The Psychology of Mood and Mood Regulation. England: Addison-Wesley Longman.

Spada, N., \& Lightbrown, P. (1993). Instruction and the development of question in the L2 classroom. Studies in Second Language Acquisition, 15, 205-221.

Troike, M. S. (2006). Introducing Second Language Acquisition. New York: Cambridge University Press.
Woozley, I. (2012). Second Language Acquisition and Communicative Approach. Retrieved June 4, 2012, from Niigatajet/documents/secondlanguage-acqusition.pdf.

Xiangui, Z. (2005). Learning theories and second language learning. CELEA Journal, 28(5), 1-8 . Retrieved from http://www.celea.org.cn/teic/63/6 3-120.pdf. 